\title{
Primary squamous cell carcinoma of the stomach: a rare entity
}

\author{
Mhairi Little, P C Munipalle, Viswanath Y K S
}

Department of Surgery, South Tees NHS Hospitals Foundation Trust, Middlesbrough, UK

\section{Correspondence to} P C Munipalle, munipalle@doctors.org.uk
To cite: Little $M$,

Munipalle PC, Y K S V. BMJ Case Rep Published online: [please include Day Month Year] doi:10.1136/bcr-2013009706

\section{SUMMARY}

A 73-year-old man presented acutely with upper gastrointestinal (GI) haemorrhage. Upper GI endoscopy was suggestive of a pancreatic or submucosal duodenal neoplasm invading the stomach. He underwent laparoscopically assisted distal gastrectomy. Histopathological examination showed the rare entity of primary gastric squamous cell carcinoma. He underwent adjuvant chemotherapy and remains disease free at 6 months.

\section{BACKGROUND}

The vast majority of gastric cancers are adenocarcinomas and squamous cell carcinoma (SCC) of the stomach is very rare. Less than 100 cases have been reported in the literature. ${ }^{1}$ The pathogenesis is not well understood and a number of mechanisms for its development have been suggested. We present a case of locally invasive squamous cell carcinoma arising in the gastric antrum which presented as acute upper GI haemorrhage. We discuss diagnostic criteria, current management strategies and reported outcomes.

\section{CASE PRESENTATION}

A 73-year-old man presented to the hospital with malaena. He had no medical or surgical history of note.

\section{INVESTIGATIONS}

Haemoglobin at admission was $6 \mathrm{~g} / \mathrm{dl}$. After stabilisation with supportive treatment and blood transfusion, urgent upper GI endoscopy was carried out. This showed a large mass in the gastric antrum with ulceration of the first part of the duodenum (figure 1). Staging CT showed a mass involving the pancreatic body, proximal and middle duodenum and gastric antrum.

\section{DIFFERENTIAL DIAGNOSIS}

The provisional diagnosis was that of a pancreatic or submucosal duodenal neoplasm eroding into the stomach.

\section{TREATMENT}

The patient was transferred to the regional tertiary upper GI unit where he underwent laparoscopic exploration. The tumour was seen invading the pancreas, mesocolon and superior mesenteric artery origin and clinically resembled a gastrointestinal stromal tumor tumour; laparoscopically assisted palliative distal gastrectomy was carried out and a feeding jejenostomy was inserted. The patient recovered uneventfully from surgery.

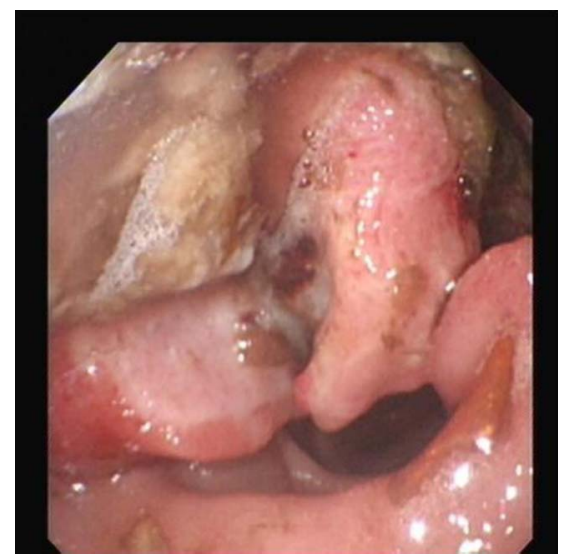

Figure 1 Endoscopic view of tumour.

\section{OUTCOME AND FOLLOW-UP}

Macroscopically, the tumour measured $80 \times 50 \times$ $55 \mathrm{~mm}$ (figure 2). Histopathological examination showed a well-differentiated SCC of the gastric antrum and proximal duodenum with an extension through serosa into the pancreas and mesocolon. Immunohistochemistry was positive for cytokeratins $\mathrm{AE} 1 / \mathrm{AE} 3$ and CK5 and for p63 (figure 3). Extensive sampling failed to identify any glandular tissue. Excision appeared incomplete with the involvement of the pancreas. The pathological staging was therefore pT4 pN0 pMX R1. No evidence of occult SCC was found elsewhere in the body. The patient underwent adjuvant chemotherapy. Follow-up CT scan showed no evidence of metastatic disease.

\section{DISCUSSION}

Given that the stomach is lined by glandular epithelium, it is not surprising that the vast majority of stomach cancers are adenocarcinomas. Other

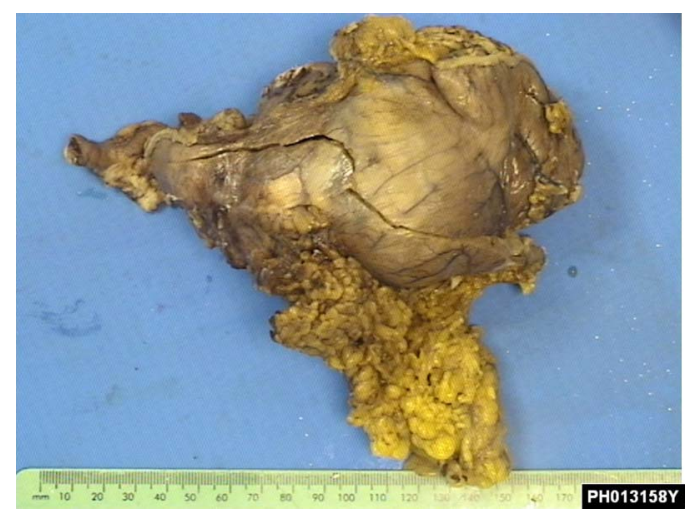

Figure 2 Macroscopic view of tumour. 


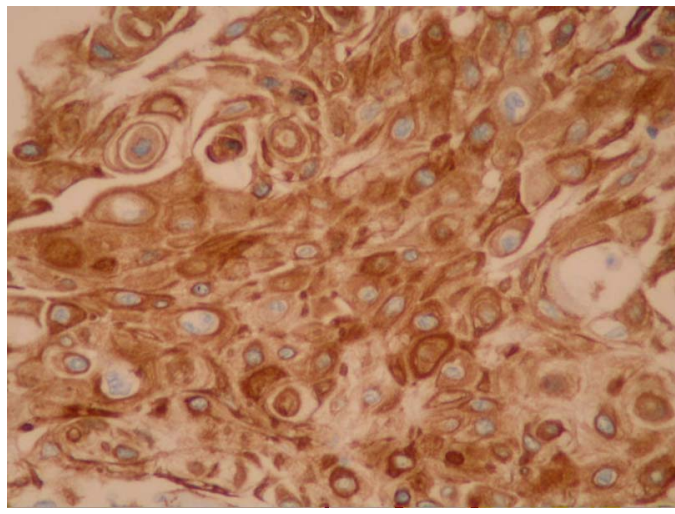

Figure 3 Immunohistochemical staining.

tumours such as lymphoma, carcinoid and stromal tumours occur less commonly. Primary SCC of the stomach was first reported in $1895^{2}$ and remains a rare entity. Male preponderance $(5: 1)$ was observed ${ }^{3}$ among the nearly 100 cases reported. This is a condition of the aged population; however, it has been seen in a 17-year-old boy. ${ }^{4}$ More aggressive lymphovascular invasion than adenocarcinoma was observed. ${ }^{5}$

In order to reach a diagnosis of primary SCC of the stomach, alternative sources for malignant squamous cells have to be excluded. For example, islands of squamous cells originating from the oesophagus may exist in the cardia and can be a potential source for the development of SCC. SCCs originating in the oesophagus itself may extend into the stomach by direct invasion. Primary SCC may originate elsewhere in the body (eg, head and neck, lung) and metastasise to the tissues of the stomach. Metastatic disease from such sites may be ruled out by clinical examination including skin and upper aerodigestive tract, radiological studies and endoscopic examination.

In view of these alternative pathologies, Parke ${ }^{6}$ suggested three criteria for the diagnosis of primary SCC of the stomach:

- Tumour not located in the cardia

- Tumour not extending into oesophagus

- No evidence of SCC elsewhere in the body

In addition to these criteria, Boswell and $\mathrm{Helwig}^{7}$ defined four histopathological features required for the diagnosis of primary gastric SCC: the presence of keratinising cell masses with pearl formation, a mosaic pattern of cell arrangement, intercellular bridges and high concentrations of sulfhydryl or disulfride groups which indicate keratin production. The absence of glandular tissue excludes the more common adenosquamous carcinoma.

The mechanism by which SCC develops in the glandular tissue of the stomach remains elusive. Several pathological processes have been suggested, the most popular suggestion being malignant transformation in an area of squamous metaplasia. The development of SCC in the absence of metaplasia but associated with chronic inflammation was also reported. ${ }^{1}$ Other potential sources of squamous components proposed by Straus et $a l^{8}$ include:

- Squamous differentiation of an adenocarcinoma with complete replacement of glandular elements.

- Endothelial cells or squamous metaplasia of gastric vessels.

- Islands of squamous cells in gastric mucosa.
- Totipotent stem cells capable of differentiating into cells of any type.

Owing to the rarity and advanced presentation of primary SCC, there is a lack of evidence to support a particular management strategy and prognosis is difficult to predict.

Surgery to achieve R0 (no residual tumour) resection remains the mainstay of the treatment, well supported by adjuvant therapies as reported by us. Adjuvant radiotherapy following surgical resection and subsequent chemotherapy to downstage and resect a liver metastasis resulted in a 5-year symptom-free survival. $^{3}$ Good response to chemoradiotherapy of recurrence following surgical resection was reported by Michalet ${ }^{9}$ also.

Good long-term survival has been reported with chemotherapy alone despite locally invasive tumours. Yildrim et al ${ }^{10}$ reported a case of advanced gastric SCC with dissemination to adjacent organs, which showed complete remission for 3 years on adjuvant therapy with $5 \mathrm{FU}$ and Cisplatin.

However, not much information is available on the neoadjuvant role of chemoradiotherapy in gastric SCC, in comparison with other upper aero-digestive tumours like oesophageal SCC where it has been shown to have a definite role. Further studies would benefit the patients affected by this rare disease.

\section{Learning points}

- Primary gastric squamous cell carcinoma is rare.

- To reach a diagnosis of primary squamous cell carcinoma, a number of clinical and pathological criteria need to be fulfilled.

- Primary gastric squamous cell carcinoma can present acutely with upper gastrointestinal haemorrhage.

- Tumours are primarily managed surgically, although adjuvant chemotherapy and radiotherapy also have a role.

Competing interests None.

Patient consent Obtained.

Provenance and peer review Not commissioned; externally peer reviewed.

\section{REFERENCES}

1 Callacondo D, Ganoza-Salas A, Anicama-Lima W, et al. Primary squamous cell carcinoma of the stomach with paraneoplastic leucocytosis: a case report and review of the literature. Hum Pathol 2009;40:1494-8.

2 Muto M, Hasebe T, Muro K, et al. Primary squamous cell carcinoma of the stomach: a case report with a review of Japanese and Western literature. Hepatogastroeneterology 1999;46:3015-18.

3 Schmidt C, Schmid A, Lutteges JE, et al. Primary squamous cell carcinoma of the stomach. Report of a case and review of literature. Hepatogastroenterology 2001;48:1033-6.

4 Schwab G, Wetscher G, Dietze 0, et al. Primary squamous cell carcinoma of the stomach in a seventeen-year-old boy. Surg Today 1992;22:561-4.

5 Volpe CM, Hameer HR, Masetti $P$, et al. Squamous cell carcinoma of the stomach. Am Surg 1995;61:1076-8.

6 Parke RE. Squamous neoplasms of the stomach. Am J Roentgenol 1967;101:447-9.

7 Boswell JT, Helwig EB. Squamous cell carcinoma and adenoacanthoma of the stomach. A clinicopathological study. Cancer 1965;18:181-92.

8 Straus R, Heschel S, Fortmann DJ. Primary adenocarcinoma of the stomach, a case report and review. Cancer 1969;24:985-95.

9 Michalet V, Gaudin JL, Bancel B, et al. Squamous cell carcinoma of the celiac area. Report of a case and review of the literature. Gastroenterol Clin Biol 2002;26:1168-71.

10 Yildirim $Y$, Akcali Z, Bilezikci B, et al. Primary squamous cell carcinoma of the stomach: a case report. Tumori 2005;91:440-2. 
Copyright 2013 BMJ Publishing Group. All rights reserved. For permission to reuse any of this content visit http://group.bmj.com/group/rights-licensing/permissions.

BMJ Case Report Fellows may re-use this article for personal use and teaching without any further permission.

Become a Fellow of BMJ Case Reports today and you can:

- Submit as many cases as you like

- Enjoy fast sympathetic peer review and rapid publication of accepted articles

- Access all the published articles

- Re-use any of the published material for personal use and teaching without further permission

For information on Institutional Fellowships contact consortiasales@bmjgroup.com

Visit casereports.bmj.com for more articles like this and to become a Fellow 